\title{
The Economics and Politics of Trade Policy: An Empirical Analysis of ITC Decision Making
}

\author{
Wendy L. Hansen \\ Department of Political Science \\ University of New Mexico
}

\author{
Thomas J. Prusa \\ Department of Economics \\ Rutgers University \\ and NBER
}

May 20, 1996

\begin{abstract}
We study the determinants of trade policy decisions focusing specifically on antidumping and countervailing duty statutes administered by the International Trade Commission (ITC). Using detailed industry, import, and political pressure data we model ITC decision-making, weighing the relative impact of economic and political factors in predicting policy outcomes. We find the ITC's decision-making is significantly influenced by both economic and political factors. However, because an industry has much greater ability to create political pressure than induce economic injury, our results highlight the strategic importance of oversight representation and PAC contributions in an industry's bid for protection.
\end{abstract}

Send Correspondence to: Thomas J. Prusa, Department of Economics, Rutgers University, New Jersey Hall, New Brunswick, NJ 08903-5055, email: prusa@rci.rutgers.edu 


\section{INTRODUCTION}

In recent decades, the rise in international competition has led many U.S. firms to seek protection from foreign imports. Particularly noteworthy in the 1980s was the increased use of administered protection; that is, protection not granted directly by Congress but by administrative agencies. The two most popular trade statutes of this type are the antidumping (AD) and countervailing duty (CVD) statutes, which allow U.S. firms or industries to seek protection from alleged unfair trade practices, namely dumping and subsidization.

Under these laws, U.S. firms or industries apply simultaneously to the Department of Commerce (DOC) and the U.S. International Trade Commission (ITC); these agencies have the authority granted by Congress to determine, respectively, whether or not an unfair practice has occurred and whether or not the unfair practice has caused injury to the U.S. industry. Affirmative decisions by both of these bodies generally result in the imposition of higher tariffs designed to counter the alleged unfair practice.

In theory, protection granted by these bureaucratic agencies is purely a function of the rules and procedures defined by U.S. trade laws. According to the statutes, once an industry files its request for protection, the DOC and ITC merely apply Congress' current rules to the case-specific economic data and then make their determinations.

In practice, there is considerable question whether the process is as pure and apolitical as the statutes imply. The outcomes of cases are not determined in a political vacuum; administered protection may have more to do with "whom you know," timing, and surrounding circumstances than with the strength of the case under the statutes. For instance, an industry with representatives on important international trade subcommittees might find its request for protection treated more favorably by policymakers than 
it would without such representation. Other types of political leverage such as PAC contributions may also indirectly pressure ITC commissioners. Similarly, petitioners filing against non-market economies may find the proceedings particularly easy, while those filing against countries with which the U.S. has security alliances might find that policymakers are subject to pressure from the State Department and Executive branch to deny protection.

In this paper we study ITC decision making in an attempt to determine to what degree both economics and politics affect administered protection. Since the DOC rejects only $5 \%$ of its petitions, we limit our attention to the decision making behavior of the ITC. Using detailed industry, import, and political pressure data we model ITC decision making, weighing the relative impact of economic and political factors in predicting AD and CVD outcomes.

Our research complements and extends a number of other studies of the ITC. Finger, Hall and Nelson's (1982) research was a seminal early study that neatly framed the debate over the relative importance of economic criteria and political pressure. They found that for cases filed between 1975-1979 political pressure plays a significant role in ITC decision making, especially for AD and CVD decisions.

More recent research has emphasized the primary importance of economic criteria rather than political pressure and hence has raised considerable doubt about Finger, Hall and Nelson's findings. For example, Herander and Schwartz (1984), Baldwin (1985), Goldstein and Lenway (1989), and Anderson (1993) all find that politics have little to do with ITC decisions; rather they find that protection is predicted by economic measures, such as the size of the dumping margin and changes in shipments, etc. Moore (1992), DeVault (1993), and Baldwin and Steagall (1994) analyze the individual voting behavior of ITC commissioners, incorporating both economic and political factors into their 
models. They all find little evidence of political pressure swaying ITC decisions. ${ }^{1}$ One interpretation of these studies is that the Trade Agreement Act of 1979, by making $\mathrm{AD}$ and CVD procedures more precise and transparent, reduced the role for political pressure.

Hence, most recent research concludes that the ITC is relatively immune to political pressure. However, there are at least three important reasons why we believe these results should be reconsidered. First, the three studies which control for commissionerspecific effects may be biased against measuring the influence of political pressure. Only the majority opinion of the voting commissioners determines a case's outcome. The fact that political pressure is not important for almost all commissioners does not imply that such pressure does not change the outcome (e.g., by changing a single vote in split decisions); commissioner-specific analysis might also be biased due to strategic voting behavior by the commissioners. ${ }^{2}$ In order to avoid this potential problem we believe it is important to focus on the overall ITC decision.

Second, all of these earlier studies' estimates are based on a very small set of ITC decisions (less than 100) even though over 700 AD and CVD cases were filed between 1980 and 1988. For example, Anderson considers only 67 ITC decisions and DeVault estimates are based on data from fewer than 50 cases. These authors are limited to such a tiny fraction of cases because they gather data only when it appears in published ITC reports and most data only appears in the public reports when stringent confidentiality

\footnotetext{
${ }^{1}$ Baldwin and Steagall emphasize that ITC commissioners vary tremendously in terms of which economic factors affect their decisions. This is arguably an indication of the considerable discretionary power afforded to commissioners under the statutes and points to the potential for political influencebut such pressure is not significantly estimated.

${ }^{2}$ In an attempt to appear independent of political pressure, a commissioner may vote negative, but does so only if he or she knows that the overall outcome will be positive. So, while the individual may appear not to be influenced by Congressional pressure, the vote of the individual may merely be strategic and actually wouldn't affect the final outcome.
} 
requirements are satisfied. In general, data is published in ITC reports only when doing so does not reveal information that might be viewed as "business confidential." As a result, cases involving industries with relatively high concentration ratios (or when a small number of firms are involved in the petition) will not have data published in the public reports. In other words, the failure to find evidence of political pressure may be due to the fact that the estimates are based solely on public cases - and open and public cases are precisely when one would expect limited political pressure. We overcome this problem by augmenting information from the public ITC reports with detailed data from other sources. For instance, the public ITC reports always report the tariff line items (TSUSA) under investigation. Instead of relying on the ITC reports for import data (which is data that must satisfy the confidentiality requirements) we use the TSUSA codes to gather data from the Department of Commerce's annual import data series. This allows us to base our estimates on a far larger sample: over $400 \mathrm{AD}$ and CVD cases. ${ }^{3}$ Thus, our data set is not biased by having to exclude cases involving confidentiality. However, this does mean that some of our measures of economic injury are more aggregated than those used in some of the earlier studies. But, since many cases involve firms who, because of product diversification, encompass broad industry categories, aggregation may not significantly impair our estimates. Given that we find our measures of economic injury significant, we feel this is the case.

Third, our political measures are both broader in scope and also more precise than those used in other studies. For instance, we include monetary contributions of industry Political Action Committees (PACs) to trade oversight committee members in the House and Senate. To our knowledge we are the first to implement such a direct

\footnotetext{
${ }^{3}$ We must drop a large number of agricultural cases from our analysis since measures of economic injury such as capacity utilization are not available.
} 
measure of political influence, and we find that PAC contributions do increase an industry's likelihood of receiving protection, especially for $\mathrm{AD}$ cases. In addition, while earlier researchers incorporate measures of congressional oversight in their studies, our measures of oversight representation are more precise. For instance Moore simply uses a dummy variable which equals 1 if the petitioning industry has production facilities in one oversight committee member's district for the House or Senate; DeVault uses only the number of "active" firms in a petition, which he defines as firms who petition, appear at the ITC Hearings, or are listed as supporters of the petitioners. While Moore's measure fails to capture variation in the degree of potential congressional influence, DeVault's measure ignores firms in the industry that have a stake in the outcome but may choose to participate in other ways, such as contributing to PACs or directly lobbying congressmembers. Since ITC outcomes affect an entire industry, firms that are active in other ways, perhaps out of a concern for their reputation or possible negative publicity, should not be ignored. By contrast, we believe our measure of oversight representation, the number of Ways and Means Committee and Senate Finance Committee oversight members' districts wherein the domestic industry operates, along with PAC contributions more accurately captures political pressure.

After constructing our data for AD and CVD cases filed between 1980 and 1988, we then estimate the ITC's decision function. We find that both economic and political considerations significantly affect the ITC's decision making. Our results not only verify Finger, Hall and Nelson's finding that political pressure enhances an industry's likelihood of receiving protection but also are consistent with the more recent studies' conclusion that economic measures of injury are important. We interpret our results as confirming that both economics and politics are important for ITC decisions.

We then use our estimates to quantify how much an industry's plea for ITC pro- 
tection is increased by being located in a district whose representative is a member of a trade committee as compared to when the industry does not have such a political ally. We also quantify how changes in economic measures of injury, such as capacity utilization and shipments, affect the likelihood of protection.

The remainder of the paper is organized as follows. In the next section we examine the decision making process of the ITC and the nature of its decisions. In section 3 we discuss various factors that may influence the decisions of the ITC commissioners. In section 4 we econometrically analyze the decision making behavior of the ITC. In section 5 we provide measures of the impacts of political and economic factors on ITC decision making. Finally, we draw some general conclusions about the decision making behavior of the ITC and discuss the implications for public policy.

\section{BACKGROUND}

Generally speaking, there are three possible outcomes for an AD or CVD petition. First, a case can be rejected. For instance, if the DOC makes a negative ruling in its final investigation, the case is dismissed, no protection is granted and no final ITC determination is made. A case is also dismissed if either the ITC's preliminary or final investigation is negative. Note however that since the DOC only rarely makes a negative ruling, whether or not the petition for protection is granted virtually always hinges on the ITC's decision. ${ }^{4}$ Second, if both bureaucratic agencies' final determinations are affirmative, then a duty (tariff) is levied on the named country's imports; the size of the duty is determined by the DOC in its investigation of the alleged unfair practice. Finally, a case can be "settled," which generally means in the case of AD petitions that

\footnotetext{
${ }^{4}$ The papers in the volume edited by Boltuck and Litan (1991) discuss DOC procedures. Several of these papers argue that the DOC's rules governing AD and CVD actions are heavily biased in favor of U.S. industries, often making it questionable that any "unfair" trade act was actually committed.
} 
the foreign firms agree to raise their prices and stop dumping, and in the case of CVD petitions that the foreign government agrees to reduce or remove the subsidy granted to its firms. During the 1980s each type of outcome accounted for about one-third of all $\mathrm{AD}$ and CVD cases.

In Table 1 we give a breakdown of cases by country and outcome for the 1980-1988 period. ${ }^{5}$ We report the breakdown for $\mathrm{AD}$ and CVD cases separately and also for all "Title VII" cases (a term encompassing both AD and CVD petitions referring to the section of trade law where the statutes appear). On average, during this nine year period, over 80 Title VII cases a year were filed against a diverse group of countries: developed, developing, and non-market economies. There are several interesting patterns to the filings and outcomes. First, Title VII actions are filed primarily against the U.S.'s major trading partners - $50 \%$ of the petitions are filed against developed countries. Second, developing countries are subject to a disproportionate share of CVD duties: almost seven of ten affirmative CVD actions are taken against developing countries. Further, many CVD cases against developing countries result in some type of settlement agreement. Taken together, it appears that CVD law is an effective weapon against trade from developing countries. Third, European countries fare relatively well under both types of administrative proceedings. Less than $20 \%$ of Title VII cases against European countries have resulted in duties being levied. A large number of cases against European countries, however, do result in settlements. In contrast, cases filed against Japan and the NICs have been relatively successful. For example, $50 \%$ of the cases against Japan resulted in duties being levied. Finally, while non-market economies have been subject to relatively few investigations (especially CVD) the rejection rate is also low. Of course,

\footnotetext{
${ }^{5}$ In 1988 the U.S. changed from the old tariff schedule (TSUSA) to the "Harmonized Tariff Schedule." Concordance problems limit our analysis to TSUSA data only, and hence to the 1980-1988 period only.
} 
these raw statistics by themselves do not necessarily reflect a country-specific bias, since, for example, it may be that industries filing cases against Japan have also experienced large lay-offs and excess capacity problems, or that Japanese corporate culture makes them more likely to engage in so-called unfair practices.

\section{Modelling ITC Decision Making}

In this section we model the decision making behavior of the International Trade Commission. Drawing on previous research we incorporate both economic and political factors into our model that may affect whether or not a Title VII petition receives protection. Clearly, we expect measures of economic injury to be positively related to affirmative ITC decisions, since this is stipulated in the statutes. However, it is widely agreed that political and more general economic pressures also influence ITC decision making. For instance, the U.S.'s large and growing trade deficit might raise the public's ire over trade-related problems, and thereby create substantial pressure for more affirmative ITC decisions, regardless of whether the less than fair value (LTFV) imports have statutorily caused injury. Or, a petition filed by an industry with production facilities located in districts of representatives who sit on trade oversight committees might have more success than a petition filed by an industry that does not have a representative who can effectively lobby the Commission on its behalf. Below we discuss the variables used to measure these influences. A more detailed description of the variables used in our models is provided in the data appendix. 


\section{Political Pressure}

According to economic theories of regulation (Stigler, 1971; Peltzman, 1976; Becker, 1983), interest groups compete for regulatory benefits from politicians by lobbying and applying pressure, and politicians grant regulatory benefits to interest groups in such a way as to maximize their political support. Here, interest group activities form the demand side of a "market" in which politicians supply regulatory policy benefits.

This theory emphasizes the consequences of regulatory policy in terms of the distribution of political benefits. However, the theory does not explain how interest groups influence regulators, nor what the relationship is between politicians and bureaucrats in the regulatory policy process; it simply assumes that interest group pressures are exerted on regulators, and it treats politicians and bureaucrats as the same actors (regulators). In order to correct this deficiency, several scholars (Weingast and Moran, 1983; Weingast, 1981, 1984; McCubbins and Schwartz, 1984) developed the so-called congressional dominance theory. As discussed in Baldwin (1985) and empirically examined in Hansen (1990), Congressional oversight committees can exert a great deal of pressure on ITC commissioners not only via direct lobbying but also through budgetary control. The theory holds that Congressmembers possess sufficient rewards and sanctions to create an incentive system for bureaucratic agencies, and that bureaucrats follow Congressmembers' preferences under this incentive system. Congressional committee oversight is perceived as a mechanism used to increase Congressmembers' control over

bureaucrats, with members of Congress choosing to serve on the committee in which the interest groups in their districts have the most stakes (Shepsle, 1979). In the committees, members of Congress use several rewarding and sanctioning methods to control the behavior of bureaucrats, such as budget allocation, oversight hearings, legislation, 
and appointment confirmation.

Both the economic theory of regulation and the congressional dominance theory suggest that trade policy decisions of the government are influenced by interest group pressures, often delivered to bureaucrats through Congressmen in the oversight process. Three actors are involved in the process: interest groups, politicians, and bureaucrats. Interest groups seek to maximize their wealth by lobbying politicians; politicians seek to maximize their political support from interest groups by delivering interest group pressures to bureaucrats; and bureaucrats seek to maximize agency budgets, subject to politicians' rewards and sanctions.

In our model, we develop several testable hypotheses for the regulation of trade that come out of this body of pluralist literature. The first testable hypothesis presented in our model is that the political power of an industry may affect policy outcomes. This is operationalized with two measures: industry size and concentration. It is hypothesized that large industries are likely to receive greater protection than small industries. Although groups that are small relative to the size of any opposing group are more effective at organizing and taking action (Olson, 1965), they lack economies of scale in the production of pressure (Becker, 1983). Moreover, a large industry is able to provide more votes, money, organization, and thus influence. The size of an industry is measured by its industry employment. Second, it is hypothesized that more concentrated industries are more likely to receive protection than less concentrated industries. Generally, concentrated industries with a handful of dominant firms will be more effective in obtaining protection than industries with many small firms. With fewer free rider problems, more opportunities to reach a consensus, and fewer communication problems among members, they may be more organized and better at pressuring policy makers. The degree of concentration in an industry is measured by a concentration ratio which 
is taken as the percentage of output by the four largest firms in the industry.

In addition to size and concentration affecting pressure group influence on policy formation, we hypothesize that political representation of industries in Congress may be an important factor in securing protection. In particular, we maintain that industries located in the districts of oversight committee members are more likely to be protected than are other industries. Under a system of fragmented jurisdiction, members of an oversight committee gain responsibility and rights over a designated set of issues. Their important rights include near-monopoly power over proposals to alter policy and complete veto power over proposals made by others (Weingast, 1984). In the area of trade policy, the House Ways and Means Committee and the Senate Finance Committee have oversight power. Committee members may provide protection to the import-competing industries in their districts, and can pressure bureaucratic agencies like the ITC and DOC in various ways, including holding hearings, making legislation, and decreasing their budgets. In our model, industry representation on the oversight committee is measured by counting the number of Ways and Means Committee and Senate Finance Committee oversight members' districts wherein the domestic industry operates. For example, an industry is represented by five Ways and Means Committee members if it has operations in five of the districts represented on the Committee.

Third, the amount of campaign contributions that industries give to politicians can represent the political activity or strength of an industry, thus affecting not only the amount of pressure Congressmembers feel from that industry but also their support for the industry. Though no previous research has considered the indirect influence of campaign contributions on ITC decisions, other studies have shown that political action committee (PAC) contributions have substantial effects on the behavior of politicians. For example, Silberman and Durden (1976) find that an increase in total labor contri- 
butions led to a significant increase in Congressmembers' support for a minimum wage bill. Chappell (1982) and Brown (1983) report similar findings in defense and health care policy areas. Our hypothesis is that industries (via their PACs) contribute to the oversight members' campaigns and that more pressure will be exerted on the ITC on behalf of those industries who made larger contributions. We measure an industry's PAC contributions by the total amount of contributions to all oversight committee members.

\section{Economic Measures of Injury}

By statute, the ITC is directed to take into account the economic situation of an industry in determining injury. U.S. law directs the ITC to consider a wide variety of economic factors when determining injury, among these evidence of price undercutting, domestic sales, capacity utilization, employment, profits, productivity, and volume of unfairly traded imports. This is not an exhaustive list of criteria, nor is the ITC required to consider each or every factor in making its decisions (Kaplan, 1991). These caveats aside, one would expect evidence of economic hardship or decline to be an important element of the ITC's decision making. However, many of the economic factors delineated in the law are highly correlated in our sample. While the regression coefficients can be estimated, the high multicollinearity implies that the parameters possess large standard errors. In addition, since (i) the other estimated coefficients do not significantly change and (ii) the variables where multicollinearity is most problematic (shipments and employment) are insignificantly estimated whether estimated together or separately, we report results where we use percentage changes in industry capacity utilization and shipments to measure recent industry performance. ${ }^{6}$ One would expect that the greater the fall in

\footnotetext{
${ }^{6}$ Specifications including percentage change in employment are available upon request from the authors.
} 
each variable, the greater the likelihood of an affirmative decision.

Additionally, the volume of unfairly traded imports is a key factor in the ITC's injury determination; it is almost always cited as an important component of Commissioners' decisions. The notion is that the imports under investigation are close substitutes for domestic products, and therefore a large volume of imports is arguably evidence of lost domestic sales (i.e., injury). This suggests that a country with a large share of the U.S. import market is more likely to have caused injury to the competing U.S. industry. In order to examine the importance of volume of the unfairly traded imports for the ITC's injury determination, we include the import market share of the named country in our analysis. This measure of market share is identical to that recorded in the ITC's reports. ${ }^{7}$

\section{Other Control Variables}

\section{Case Specific Factors}

Even though ITC commissioners are not required to consider the LTFV margin when making their injury determination, one might expect to find a relationship between the LTFV margin and the likelihood of injury. Commissioners may view large duty margins prima facie as evidence of injury. While Palmeter (1987) offers a different view arguing that the ITC relies more on the volume of LTFV imports rather than the LTFV margin, we also investigate our hypotheses by including the LTFV margin as an independent variable. Furthermore, our hypothesis is consistent with the use of a "bifurcated" approach where commissioners make a two stage decision, first determining

\footnotetext{
${ }^{7}$ Though this measure is often deleted from the publicly released version of the ITC's reports, we were able to re-create this measure by using the Commerce Department's TSUSA-level import data. See the appendix for a more detailed description.
} 
whether material injury exists and then determining whether injury is due to dumped or subsidized imports.

In addition, we control for the fact that steel and steel-related industries were by far the largest users of Title VII laws during the 1980s. Besides the possibility of injury discussed above, the notion here is that petitions filed by steel and steel-related industries may be more successful due to this industry's frequency of filing (i.e., learningby-doing), the importance of steel to the national interest, or the inordinate amount of public attention steel cases tend to receive. We include a dummy variable to capture any special treatment the steel industry may receive.

\section{Macroeconomic Influences}

Trends in the aggregate economy are also likely to influence the ITC. An industry experiencing a decline in sales and profits when the economy is in the midst of a recession is likely to find it more difficult to show that unfair imports are causing its troubles. Assuming that U.S. imports are more sensitive to domestic income changes than exports are; the U.S. trade deficit will capture trends in the macro-economy; one would expect a negative relationship between injury and the trade deficit. On the other hand, a large trade deficit may create additional political pressure on the ITC to provide trade relief. If this is the case, one would expect a positive relationship between injury and the trade deficit.

We also control for additional aggregate trends with dummy variables for each of the years included in our data (with 1980 as the base year of comparison). For instance, changes in the membership of the ITC might lead all cases filed in some years to be more successful. 


\section{Microeconomic Influences}

It is often argued that administered protection serves to substitute for the more traditional, but GATT-constrained mode of protection, namely tariffs (Baldwin, 1985; Hoekman and Leidy, 1989; Hansen and Prusa, 1995). Although there is no statutory requirement that there be a connection between increased imports and tariff concessions, we hypothesize that the pleas of industries who have low levels of protection-or have lost protection-will be more successful. In other words, the lower the current tariff, the more likely bureaucrats will use Title VII duties to compensate for lost protection.

Similarly, while Title VII protection is supposed to be granted in response to injury caused by a particular unfair trade action, it may be more appropriately thought of as compensation for overall market share gains by foreign rivals. In other words, Title VII may serve to protect those industries that have experienced the greatest overall import competition. As a measure of general import gains, we construct an industry-level measure of foreign penetration [imports/(output+imports-exports)]. Note that foreign penetration is a far more aggregated index than the measures of import gains reported in the ITC's reports (discussed above) and thus is capturing general industry-wide trends rather than the market share gains by the named importers. If this hypothesis is correct, increased foreign penetration makes it easier for the ITC to make an affirmative injury decision.

Named Country

There is some evidence that the identity of the named country influences ITC decisions. For example, in Table 1 we saw that European countries seemed to fare better than Japan, NICs, or non-market economies. Even after controlling for other factors, peti- 
tions against Japan might be treated differently in ITC decision making because of the overwhelming negative attention that Japan received during the 1980s in trade-related matters. Given its situation, one might expect that petitions against Japan would be more likely to receive a positive ITC ruling. Similarly, the rapid export-oriented growth of the NICs might hurt them in ITC hearings. On the other hand, the historically strong relationship and trade ties between Europe and the U.S. may lead to more favorable treatment for their industries. Or a fear of retaliation from European countries may dampen enthusiasm for protection. Finally, cases filed against non-market economies may tend to be more successful, both because of cold-war suspicions and also because of the heavy reliance on "constructed value" measures of home market performance when non-market economies are involved (Tharakan, 1991). Alternatively, it may be the case that the corporate cultures in Japan or the NICs might imply their firms are more likely to engage in dumping behavior. Or, it may be that certain governments are more likely to engage in subsidization. We control for country-specific differences by including dummy variables for petitions against each of the following: Japan, Newly Industrialized Countries (NICs), West European countries, and non-market economies.

\section{Estimating ITC Decision Making}

Our data set is comprised of the Title VII cases filed between 1980 and 1988 subject to the following restrictions. First, we drop cases rejected by the Commerce Department (since the ITC never makes its final decision when no unfair practice is found). This eliminates only about $5 \%$ of the cases. Second, since most of our measures of economic criteria are unavailable for the agricultural sector, we restrict our sample to manufacturing industries. Third, we drop CVD cases against industries located in countries 
who have not signed the GATT subsidy code since an injury decision is not required for these countries.

Whether or not to exclude settled cases (which receive no official ITC decision) is a difficult decision. If settled cases are excluded, then our model estimates the ITC's decision function. In this case, our parameter estimates can be interpreted as the impact on the probability that a duty will be levied. On the other hand, if settled cases are included, then our model estimates, more broadly, the probability that a Title VII petition will result in some type of trade measure being taken (i.e., either a duty levied or a settlement). In addition, since many settlements are achieved via government to government negotiations, one might expect that political pressure will play an even greater role in explaining these cases. In order to address both interpretations we present the analysis both with and without settled cases. Including settled cases, we have 434 observations in the data set; if we exclude settled cases from the analysis, we are left with 313 ITC decisions. We estimate the ITC decision function for all Title VII cases (i.e., $\mathrm{AD}$ and CVD together), and separately for $\mathrm{AD}$ and CVD actions.

Our probit estimates are given in Tables 2 (excluding settled cases) and 3 (including settled). In each table we present three specifications of the estimated ITC decision function, allowing for a comparison of the relative importance of economic and political factors. ${ }^{8}$ The unrestricted model (Specification A) includes both economic and political factors. In Specification B we drop the political factors, while in Specification C we drop the measures of economic injury. All three specifications provide good estimates of the model, with the percentage of observations correctly predicted generally ranging from 75-80\%. Next to each variable we indicate whether theory implies that the estimate

\footnotetext{
${ }^{8}$ Year dummies are included but not reported due to space limitations. They are available upon request.
} 
should be positive or negative.

\section{Overall Comparison: Economic vs. Political Factors}

We test for the importance of economic and political factors by performing likelihood ratio tests of significance for the models estimated in Tables 2 and 3 . To test for significance of political pressure, we compare the goodness of fit (log likelihood) when we include measures of both economics and politics with the goodness of fit when we drop the measures of political pressure. For instance, from Table 2 we see that when we exclude settled cases, the log likelihoods are -164.15 and -170.77 (for specification A, Title VII cases). The log likelihood test is distributed $\chi^{2}(k)$, where $k$ is the number of variables dropped. Since we drop five variables that measure political pressure, $k=5$, implying the difference (6.62) has a marginal significance of 0.02115 , which is clearly significant at the $5 \%$ level.

In Table 4 we report likelihood ratio tests of significance for the models estimated in Tables 2 and 3. When settled cases are excluded, political pressure is statistically important when estimates are based on Title VII and AD cases, but insignificant for CVD cases. When settled cases are included, political pressure is statistically important for all three data sets, suggesting that politics is especially important for the decision to settle.

We also test for significance of our measures of economic injury. Once again we compare the goodness of fit-now dropping the three measures of injury $(k=3)$. For instance, from Table 2 we see that when we exclude settled cases, we compare the log likelihood of -164.15 with -171.65 (for specification A, Title VII cases). We therefore find the difference (7.5) has a marginal significance of 0.00182 , which far better than the $5 \%$ level. As reported in Table 4, our measures of economic injury are significant (less 
than 5\%) for five of six comparisons, with one at 5.6\%. Measures of economic injury are clearly important for predicting ITC decisions.

All in all, we find that in 5 of the 6 comparisons politics are significant and in 5 of the 6 comparisons economics is important. We view these results as strong evidence that ITC decisions are influenced by both economics and politics.

Finally, we also test whether separately estimating AD and CVD cases improves the results. We estimate each specification twice, once where we allow the independent variables to have separate effects for $\mathrm{AD}$ and CVD cases and once when we constrain the effects to be the same for $\mathrm{AD}$ and CVD cases (these latter estimates are reported in Tables 2 and 3). We perform likelihood ratio tests, comparing the fit for each estimation. When settled cases are excluded the fit of none of the three specifications is significantly improved; when settled cases are included, only specification A's fit is significantly improved (at the $5 \%$ level).

\section{Political Pressure}

We find that political pressure, measured by PAC contributions and House oversight, has an important influence on ITC decisions. Industries with representatives on the Ways and Means Committee have a greater chance of receiving protection; interestingly, Senate Finance oversight representation appears to be unrelated or negatively related to ITC decision making. However, it is not surprising that the House oversight influence is more significant because House members have a much more geographically narrow constituency and therefore have more narrowly defined interests; a firm filing a trade

petition will surely affect a larger fraction of a House member's constituents than a Senator's.

PAC contributions also appear to be positively and significantly related to an indus- 
try's prospects for protection, especially for $\mathrm{AD}$ cases. We believe this is an important finding, suggesting that PAC contributions alter policy outcomes - even policies being made by agencies rather than Senators or Representatives.

\section{Economic Criteria}

The named country's import market share has a positive and strongly significant effect on ITC decisions. This implies that the larger a country's import market share, the more likely the ITC will find injury. The percentage change in capacity utilization and the percentage change in shipments are proxies for changes in the industry's economic health. While both variables have the expected sign in most specifications (i.e., increases in either capacity utilization or shipments lowers the chance of protection) both are generally insignificant. We feel that the relative insignificance of these economic criteria reflects the great degree of latitude that the ITC has in making its decisions - statutory guidelines, which define the factors that determine injury and what level of injury constitutes "material" injury are extremely vague. This also explains why political pressure variables play such an important role.

\section{Country- and Industry-Specific Effects}

Importantly, we find evidence of country- and industry-specific biases. For instance the European dummy is consistently negative and significant, suggesting that the ITC is reluctant to find injury when imports are from the U.S.'s European allies. In contrast, cases against non-market economies fare particularly well (from the petitioner's perspective); the coefficient on the non-market dummy is large, positive, and significant. Interestingly, we find that there is no significant country effect for Japan and NICs. We do find, however, that the steel industry, the largest single user of Title VII law, does 
quite well at the ITC; the coefficient on the steel dummy is consistently positive and significant.

\section{Other Determinants of Injury}

Industry size and concentration ratio - our two measures of industry power - vary in sign and significance across specifications and datasets. According to Olson's theory, one should expect large, concentrated industries to fare better before the ITC. One explanation for why we find little evidence in support of this hypothesis is the ITC's increasing use of "regional injury" analysis. That is, in the early 1980s Congress amended the injury test to allow the ITC to consider only the injury to the domestic industry in a particular region (e.g., steel producers located in Northwestern states). Thus, our results suggest that Olson's theory needs to be generalized to account for the political power of industries who are large and concentrated regionally, but not nationally. In this sense, our results reject only a narrow interpretation of Olson's theory.

While the coefficient on the tariff rate is consistently negative (i.e., injury is less likely for industry's with higher tariffs), the estimates are typically insignificant. The estimates on the trade deficit and foreign penetration are also generally insignificant. The LTFV duty, however, is positive (for Title VII and AD cases) and is often significant at the $5 \%$ confidence level. This suggests that the ITC does view large duty margins as evidence of injurious imports.

\section{Putting the Estimates into Perspective}

While the estimates discussed above indicate that both political and economic factors are statistically significant, their economic importance (or real world significance) still needs 
to be quantified. Merely observing the size of the estimated coefficients is insufficient since under probit analysis the estimates can not be directly interpreted as changes in the probability of protection. In order to address this issue we calculate the estimated change in the probability of an affirmative ITC decision given a one standard deviation change in selected independent variables using our estimates found in specification A; the change in the probability is calculated relative to the selected variable's sample mean, evaluating all the other variables at their sample means. The results are reported in Table 5 .

For example, the typical petitioning industry was represented by four Ways and Means oversight members. For our sample, a one standard deviation change implies an increase in representation by three additional Ways and Means oversight members. ${ }^{9}$ This change in representation increases the probability of an affirmative decision by 19-24\% depending on whether we use the estimates from the Title VII or AD dataset.

The importance of political pressure is also evident from the impact of PAC contributions; industry contributions average approximately $\$ 174,000$ with the largest contribution (among our sample of industries) over $\$ 800,000 .{ }^{10}$ An additional $\$ 200,000$ in PAC contributions (one standard deviation) increases the likelihood of an affirmative bureaucratic decision by $6-10 \%$.

Industries can also manipulate economic criteria to improve their chance of protection (Webb, 1992; Steagall, 1995). Interestingly, our estimates imply that increasing one's economic injury may not be terribly effective. Consider for instance the effect

\footnotetext{
${ }^{9}$ The industry with the greatest representation had production facilities located in the districts of 12 Ways and Means oversight members; many industries have no representation on the Ways and Means oversight committee. A complete listing of sample means, standard deviations, etc. are provided in the appendix.

${ }^{10}$ Our measure of PAC contributions includes industry contributions to all members of the Ways and Means and Senate Finance committees.
} 
of a fall in capacity utilization. On average, the typical industry filing for Title VII protection has seen its capacity utilization fall by $5 \%$ during the previous year. Our estimates imply that an additional fall of $20 \%$ increases the probability of an affirmative ITC decision by only $4-5 \%$.

Overall, our estimates imply that country- and industry-specific factors play a huge role in determining whether or not an industry receives protection. In particular, after controlling for all other factors, non-market economy countries are $39 \%$ more likely to be found to have caused material injury, while Western European countries are $17 \%$ less likely to be found to have caused material injury. Given these findings, it should come as no surprise that in recent years non-market economies have been the subject of a large number of Title VII investigations. ${ }^{11}$ Additionally, cases filed by the steel industry are $37 \%$ more likely to be successful, a result we interpret as a reflection of the unique political pressure the steel industry is able to generate in support of its petitions.

\section{Concluding Remarks}

Although the Congress has clearly defined specific criteria that are to impact the ITC's injury determination, this paper provides substantial evidence of the ITC's vulnerability to political pressure. Most interestingly, our results suggest that despite the fact that Congress has delegated decision making to the ITC, Congressmembers seek to maintain influence over the bureaucratic agency's decisions. There is substantial support for our hypothesis that the political pressure stems from oversight committees. Our results imply, at least with respect to trade policy, that even though Congress has statutorily delegated decision making, it retains strong influence over actual policy decisions.

\footnotetext{
${ }^{11}$ During the three year period, $1989-1991$ over $15 \%$ of Title VII petitions were filed against nonmarket economies, as compared with $7 \%$ for the $1980-1988$ period.
} 
In general, the influence of oversight committee members can be beneficial, reining in bureaucratic agencies who pursue their own agendas or refuse to follow legislativelymandated procedures. However, in the case of administered protection, there is the clear danger that political pressure can cause bureaucrats to grant protection to politically powerful industries with little economic evidence of injury.

Finally, we find little evidence of the significance of traditional measures of industry power, such as industry size and concentration. At least with respect to trade policy, it appears that oversight representation and campaign contributions are the more relevant determinants of political influence. Additional research is needed to determine whether these forms of political pressure are relevant in other policy areas.

\section{REFERENCES}

Anderson, Keith B. 1993. "Agency Discretion or Statutory Direction: Decision Making at the U.S. International Trade Commission." Journal of Law and Economics, 36(2), 915-935.

Baldwin, Robert E. 1985. The Political Economy of U.S. Import Policy, (Cambridge: MIT Press).

Baldwin, Robert E. and Jeffrey W. Steagall. 1994. "An Analysis of ITC Decisions in Antidumping, Countervailing Duty and Safeguard Cases," Weltwirtschaftliches Archiv, 130(2): 290-308.

Becker, Gary S. 1983. "A Theory of Competition Among Pressure Groups For Political Influence." The Quarterly Journal of Economics, 98:371-400.

Boltuck, Richard, Robert E. Litan, editors. 1991 Down in the Dumps. (Washington, D.C.: The Brookings Institute).

Brown, Kirk. 1983. "Campaign Contributions and Congressional Voting." Paper presented at the 1983 Annual Meeting of the American Political Science Association.

Chappell. 1982. "Campaign Contributions and Congressional Voting: A Simultaneous Probit-Tobit Model." Review of Economics and Statistics 62:77-83. 
Federal Election Commission. Campaign Expenditures in the United States, various years: Reports on Financial Activity (RFA) Data, (Computer file). Washington, DC: Federal Election Commission (producer), 1977 through 1991. Ann Arbor, MI: Inter-university Consortium for Political and Social Research (distributor) , 1978 through 1992.

Finger, J. Michael, H. Keith Hall, and Douglas Nelson. 1982. "The Political Economy of Administered Protection," American Economic Review June, 452-66.

Goldstein, Judith and S. Lenway. 1989. "Interests or Institutions: An Inquiry into Congressional-ITC Relations," International Studies Quarterly 33: 303-327.

Hansen, Wendy L. 1990. "The International Trade Commission and the Politics of Protectionism," American Political Science Review, 84(1):21-46.

Hansen, Wendy L. and Thomas J. Prusa, "The Road Most Taken: The Rise of Title VII Protection," The World Economy, 18(2) 1995, 295-313.

Herander, Mark G. and J. B. Schwartz. 1984. "An Empirical Test of the Impact of the Threat of U.S. Trade Policy," Southern Economic Journal, July, 59-79.

Hoekman, Bernard M. and Michael P. Leidy. 1989. "Dumping, Antidumping, and Emergency Protection." Journal of World Trade Law, 23:27-44.

Kaplan, Seth. 1991. "Injury and Causation in USITC Antidumping Determinations: Five Recent Approaches," in P.K.M. Tharakan ed., Policy Implications of Antidumping Measures, (Amsterdam: North-Holland).

Makinson, Larry. 1989. Money and politics: The price of admission, (Washington, D.C.: Center for Responsive Politics).

McCubbins, Matthew and Thomas Schwartz. 1984. "Congressional Oversight Overlooked: Police Patrols Versus Fire Alarms." American Journal of Political Science $28: 165-79$.

Moore, Michael. 1992. "Rules or Politics? An Empirical Analysis of ITC Antidumping Decisions," Economic Inquiry, July, 449-66.

Olson, Mancur. 1965. The Logic of Collective Action. (Cambridge: Harvard University Press).

Palmeter, David N. "Dumping Margins and Material Injury: The USITC is Free to Choose," Journal of World Trade Law, 1987.

Peltzman, Sam. 1976. "Toward a More General Theory of Regulation." The Journal of Law and Economics, 19:211-48.

Shepsle, Kenneth A. 1979. "Institutional Arrangements and Equilibrium in Multidimensional Voting Models," American Journal of Political Science, 23: 27-60. 
Silberman, J. and G. Durden. 1976. "Determining Legislative Preferences on the Minimum Wage Law: An Economic Approach." Journal of Political Economy 84:317-29.

Steagall, Jeffrey W. 1995. Strategic Behavior and the United States Unfair Trade Statutes, (New York: Garland Press).

Stigler, George J. 1971. "The Theory of Economic Regulation." Bell Journal of Economics and Management Science, 2:3-21.

Tharakan, P.K.M. 1991. "East European State Trading Countries and Antidumping Undertakings," in P.K.M. Tharakan ed., Policy Implications of Antidumping Measures, (Amsterdam: North-Holland).

Webb, Michael. 1992. "The Ambiguous Consequences of Antidumping Law," Economic Inquiry, 30(3): 437-48.

Weingast, Barry R. 1981. "Regulation, Reregulation, and Deregulation: The Political Foundations of Agency Clientele Relations." Law and Contemporary Problems 44:147-177.

Weingast, Barry. 1984. "The Congressional-bureaucratic System: A Principal Agent Perspective (with Applications to the SEC)," Public Choice, 44: 147-91.

Weingast and Mark J. Moran. 1983. "Bureaucratic Discretion or Congressional Control? Regulatory Policymaking by the Federal Trade Commission." Journal of Political Economy 91:765-800.

\section{Data ApPendix}

Basic Case Information: Case outcome, date of initiation, subject, and named country, is available in the Fed-Track Guide to Antidumping and Countervailing Duty Findings and Orders. Imports subject to investigation are identified in the Federal Register by their TSUSA (line-item tariff) code. The LTFV duty is also found in the Federal Register. The four-digit SIC code corresponding to the TSUSA code can be found in U.S. Foreign Trade Statistics, Schedule 6.

Import Trade Data Products subject to investigation are identified by their line item 7-digit Tariff Schedule of the U.S.A. (TSUSA) code. There have been numerous 
changes in the TSUSA codes over the time period covered in this paper. We checked for changes in each case's TSUSA codes and where feasible, linked the revised TSUSA codes together over time. A number of cases had to be dropped because the revised TSUSA code contained products that previously had been placed in other categories. In order to further reduce the number of lost observations we aggregated the 7 -digit codes to their 5-digit equivalent. Nevertheless, a number of cases had to be dropped due to TSUSA changes.

For each case, we linked the 7-digit TSUSA codes to the Commerce Department's annual TSUSA import trade data by source country (e.g., 1/2 inch steel ball-bearings from Japan). Thus, we have very disaggregated import trade statistics (in 1982 constant dollars). Given the TSUSA codes, we were able to retrieve the import trade data by country for each case for each year 1979-1988. Import data are available on tape from the National Archives (tape series IA245). We deflated imports by the import price deflator (from Economic Report of the President).

Capacity Utilization (practical rate) at the four-digit SIC level by year was obtained from the U.S. Bureau of the Census Current Industrial Reports, Survey of Plant Capacity.

Shipments and Employment at the four-digit SIC level by year was obtained from the U.S. Bureau of the Census Census of Manufactures, Subject Series.

Concentration Ratio at the four-digit SIC level by year was obtained from the U.S. Bureau of the Census Census of Manufactures, Industry Series. 
Civilian unemployment rate is given in the Economic Report of the President. The merchandise trade deficit (millions of dollars) is also given in the Economic Report of the President.

Oversight Committee Data was measured by matching four digit SIC industry location with congressional districts. Typically, each product (which is identified by a SIC code) is produced in a number of locations across the country. If a product is produced in a district whose congressional representative (House or Senate) is a member of the Trade Subcommittee of the House Ways and Means Committee or the International Trade Subcommittee of the Senate Finance Committee, then the industry is believed to have a greater ability to influence ITC policy-making through its political pressure. The Almanac of American Politics was used to determine subcommittee membership. Data for industry location (and employment) by district and year at the four digit SIC level were obtained from the Census of Manufactures, Geographic Area Series.

PAC Contributions to oversight members were constructed using the Federal Election Commission's publicly available Campaign Expenditures in the United States Reports on Financial Activity (RFA) data. The Federal Election Commission reports contributions by each PAC to each representative and each registered candidate. Each PAC is also coded with a (self-reported) "special interest group" classification. The major task is to construct a concordance between PACs and SIC industry definitions without biasing the estimation procedure. The Federal Election Commission's special interest group classification is inadequate offering only a handful of different codes. In order to create a concordance we used the Center for Responsible Politics PAC coding 
scheme (Makinson, 1989). The CRP assigns each PAC one or more category codes which denote the industry and/or groups the committee represents. The first category is the PAC's primary industry affiliation, the second is the next most important, etc. The CRP categories are relatively detailed, offering almost 400 category codes and greatly help in identifying what industry is represented by which PACs. Unfortunately, the CRP categories were not developed with the aim of mapping into SIC industry codes, and so the classification process is still somewhat arbitrary. Where possible we assigned the CRP categories a four digit SIC code, but it was often difficult to go beyond two digit SIC codes. The results reported in this paper are based on PAC contribution at the two digit SIC level. PAC data is coded in millions of dollars.

Country and Steel Dummies: Non-market economies are defined as East Germany, Czechoslovakia, Hungary, Estonia, Latvia, Lithuania, Poland, USSR, Yugoslavia, Romania, Bulgaria, Vietnam, P.R. of China, and North Korea. West European economies are defined as United Kingdom, Ireland, Netherlands, Belgium, Luxemburg, France, West Germany, Austria, Switzerland, Spain, Portugal, and Italy. NIC economies are defined as Singapore, South Korea, Hong Kong, and Taiwan (China).

The Steel industry was defined to include the following four digit SIC codes: 3312, 3321, 3334, 3339, 3351, 3357, 3432, 3441, 3494, 3496, 3519, 3523, 3557, 3562. 


\section{Developed Economies}

Europe

France

West Germany

Spain

Italy

Belgium

United Kingdom

Other Europe

Other Developed

Japan

Canada

Other Developed

Developed Economies (total)
Total \#

Title VII

Cases Filed

Against
AD Cases

Case

Rejected

$\begin{array}{ccc}\text { Duty } & \text { Case } & \\ \text { Levied } & \text { Rejected } & \text { Settled }\end{array}$

CVD Cases

Case

Rejected Settled

Developing Countries

Brazil

Mexico

South Africa

40

39

38

38

34

30

28

52

37

39

375

Venezuela

Argentina

Thailand

Other Developing

Developing Economies (total)

228

NICs

South Korea

Taiwan

Singapore

Hong Kong

NICs (total)

6
6
3
7
1
2
2

26
9
6
68

6

6

3

7

1

2

2

26

9

6
68

68

\section{9}

12

3

13

8

9

6

17

12

11

100

\section{6}

8

8

3

3

7

6

6
5

8

8

8
2

3

56

10

2

1

1

3

3

17

37

12

10

3

1

26

7
2
0
3
2
0
9
$\mathbf{2 3}$

6

6
2

2
6

8

8
0

0
0

0
0

22

$\begin{array}{cc}8 & 2 \\ 12 & 3 \\ 2 & 0 \\ 1 & 0 \\ \mathbf{2 3} & \mathbf{5}\end{array}$

11
3
2
0
3
$\mathbf{1 9}$

5

1

1

1

2
10

20

19

150

156

108

$\begin{array}{cc}0 & 0 \\ 5 & 0 \\ 4 & 0 \\ 5 & 0 \\ 11 & 1 \\ \mathbf{2 5} & 1\end{array}$

$\begin{array}{ccc}2 & 11 & 6 \\ 0 & 7 & 6 \\ 11 & 8 & 5 \\ 1 & 10 & 4 \\ 0 & 12 & 6 \\ 1 & 7 & 5 \\ 1 & 6 & 8\end{array}$

6

5

4

6

5

8

$\begin{array}{lll}0 & 0 & 1\end{array}$

5

8

29

4

4

49

All Named Countries (total)

744

119

\begin{tabular}{ccc}
0 & 0 & 1 \\
0 & 0 & 0 \\
0 & 0 & 0 \\
0 & 1 & 0 \\
1 & 1 & 2 \\
$\mathbf{1}$ & $\mathbf{2}$ & $\mathbf{3}$ \\
$\mathbf{1 1 9}$ & $\mathbf{1 1 3}$ & $\mathbf{9 8}$ \\
\hline
\end{tabular}

Table 1. Case summary, by country, 1980-88 


\begin{tabular}{|c|c|c|c|c|c|c|c|c|c|}
\hline & \multicolumn{3}{|c|}{ Title VII Cases } & \multicolumn{3}{|c|}{ AD Cases } & \multicolumn{3}{|c|}{ CVD Cases } \\
\hline & A & B & $\mathrm{C}$ & A & B & $\mathrm{C}$ & A & B & $\mathrm{C}$ \\
\hline \multirow[t]{2}{*}{ Constant } & -0.3398 & -1.4973 & -0.0569 & -0.4012 & -1.6096 & 0.1647 & 3.3846 & -1.1987 & 1.1730 \\
\hline & $(-0.49)$ & $(-3.09)$ & $(-0.09)$ & $(-0.49)$ & $(-2.71)$ & $(0.21)$ & $(1.16)$ & $(-1.20)$ & $(0.59)$ \\
\hline \multirow[t]{2}{*}{ Size of Industry (+) } & -1.3118 & & -1.8790 & -1.8827 & & -2.4051 & 3.1372 & & 5.9167 \\
\hline & $(-1.13)$ & & $(-1.69)$ & $(-1.47)$ & & $(-1.93)$ & $(0.45)$ & & $(1.28)$ \\
\hline \multirow[t]{2}{*}{ Concentration Ratio (+) } & -0.8096 & & -0.8538 & -0.4475 & & -0.7728 & -6.1374 & & -3.6118 \\
\hline & $(-1.00)$ & & $(-1.10)$ & $(-0.51)$ & & $(-0.91)$ & $(-1.18)$ & & $(-1.24)$ \\
\hline \multirow[t]{2}{*}{ PAC Contributions (+) } & 0.8341 & & 1.4105 & 1.3004 & & 1.7071 & -0.5074 & & 0.0598 \\
\hline & $(1.44)$ & & $(2.55)$ & $(2.05)$ & & $(2.79)$ & $(-0.14)$ & & $(0.03)$ \\
\hline \# of Representatives & 0.1564 & & 0.1509 & 0.2038 & & 0.1933 & -0.6447 & & -0.3739 \\
\hline Ways \& Means Districts(+) & $(2.48)$ & & $(2.53)$ & $(3.00)$ & & $(3.01)$ & $(-1.10)$ & & $(-1.43)$ \\
\hline \# of Representatives & -0.0885 & & -0.0616 & -0.0859 & & -0.0737 & -0.1552 & & -0.0991 \\
\hline Senate Finance States (+) & $(-1.96)$ & & $(-1.44)$ & $(-1.75)$ & & $(-1.57)$ & $(-0.60)$ & & $(-0.57)$ \\
\hline \multirow[t]{2}{*}{$\% \Delta$ Capacity Utilization (-) } & -0.5423 & -0.8382 & & -0.6539 & -0.9481 & & -3.4261 & -0.8847 & \\
\hline & $(-0.94)$ & $(-1.48)$ & & $(-1.01)$ & $(-1.51)$ & & $(-1.09)$ & $(-0.52)$ & \\
\hline \multirow[t]{2}{*}{$\% \Delta$ Shipments (-) } & 0.1300 & 0.4235 & & 0.9971 & 0.6571 & & -3.9805 & -0.4287 & \\
\hline & $(0.16)$ & $(0.59)$ & & $(0.97)$ & $(0.74)$ & & $(-1.32)$ & $(-0.29)$ & \\
\hline Named Country Import & 1.8196 & 1.9082 & & 1.4008 & 1.7127 & & 4.7821 & 4.0639 & \\
\hline Market Share (+) & $(3.66)$ & $(4.10)$ & & $(2.51)$ & $(3.28)$ & & $(2.65)$ & $(2.74)$ & \\
\hline \multirow[t]{2}{*}{ Steel Industry Dummy (+) } & 0.9175 & 0.8438 & 0.8054 & 0.9549 & 0.8256 & 0.8361 & 1.6939 & 1.2129 & 0.8224 \\
\hline & $(3.64)$ & $(4.23)$ & $(3.30)$ & $(3.49)$ & $(3.77)$ & $(3.16)$ & $(1.10)$ & $(1.59)$ & $(0.89)$ \\
\hline \multirow[t]{2}{*}{ LTFV Duty (+) } & 0.6063 & 0.5822 & 0.4274 & 0.6093 & 0.6070 & 0.4829 & 0.7046 & -0.3589 & -0.4065 \\
\hline & $(1.76)$ & $(1.74)$ & $(1.28)$ & $(1.67)$ & $(1.72)$ & $(1.35)$ & $(0.37)$ & $(-0.23)$ & $(-0.26)$ \\
\hline \multirow[t]{2}{*}{ U.S. Trade Deficit (+/-) } & -0.0030 & 0.0064 & -0.0017 & -0.0034 & 0.0072 & -0.0048 & 0.0294 & 0.0009 & 0.0236 \\
\hline & $(-0.54)$ & $(1.94)$ & $(-0.39)$ & $(-0.63)$ & $(1.88)$ & $(-0.99)$ & $(1.80)$ & $(0.10)$ & $(1.92)$ \\
\hline \multirow[t]{2}{*}{ Foreign Penetration (+) } & -0.2761 & -0.2572 & -0.2885 & -0.2883 & -0.2608 & -0.1979 & -2.0997 & 1.3925 & -3.1573 \\
\hline & $(-0.39)$ & $(-0.38)$ & $(-0.42)$ & $(-0.38)$ & $(-0.36)$ & $(-0.27)$ & $(-0.62)$ & $(0.52)$ & $(-1.20)$ \\
\hline \multirow[t]{2}{*}{ U.S. Tariff Rate (-) } & -2.9654 & -1.1033 & -1.6957 & -1.4014 & -0.2479 & -1.2698 & -33.5080 & -3.9330 & -9.6412 \\
\hline & $(-0.94)$ & $(-0.40)$ & $(-0.57)$ & $(-0.40)$ & $(-0.08)$ & $(-0.37)$ & $(-1.73)$ & $(-0.42)$ & $(-0.90)$ \\
\hline \multirow[t]{2}{*}{ Non-market economy (+) } & 0.9779 & 0.9521 & 1.0088 & 0.9540 & 0.9658 & 0.9418 & & & \\
\hline & $(2.38)$ & $(2.36)$ & $(2.51)$ & $(2.23)$ & $(2.30)$ & $(2.24)$ & & & \\
\hline \multirow[t]{2}{*}{ European country (-) } & -0.4349 & -0.4379 & -0.5685 & -0.3948 & -0.3496 & -0.5240 & -0.6761 & -0.4805 & -0.7478 \\
\hline & $(-2.00)$ & $(-2.11)$ & $(-2.74)$ & $(-1.46)$ & $(-1.37)$ & $(-2.02)$ & $(-1.39)$ & $(-1.18)$ & $(-1.67)$ \\
\hline \multirow[t]{2}{*}{ NIC (+) } & 0.1890 & 0.1758 & 0.1072 & 0.1898 & 0.2284 & 0.1021 & & & \\
\hline & $(0.68)$ & $(0.66)$ & $(0.40)$ & $(0.62)$ & $(0.78)$ & $(0.34)$ & & & \\
\hline \multirow[t]{2}{*}{ Japan (+) } & -0.0783 & -0.0859 & 0.1217 & -0.0155 & -0.0247 & 0.0890 & & & \\
\hline & $(-0.26)$ & $(-0.29)$ & $(0.42)$ & $(-0.05)$ & $(-0.08)$ & $(0.29)$ & & & \\
\hline Log Likelihood & -164.15 & -170.77 & -171.65 & -119.35 & -127.86 & -123.42 & -35.93 & -39.47 & -42.36 \\
\hline Log Likelihood (constant only) & -216.76 & -216.76 & -216.76 & -158.72 & -158.72 & -158.72 & -52.36 & -52.36 & -52.36 \\
\hline \# Observations & 313 & 313 & 313 & 230 & 230 & 230 & 83 & 83 & 83 \\
\hline \# Obs. Positive & 151 & 151 & 151 & 124 & 124 & 124 & 27 & 27 & 27 \\
\hline$\%$ Obs. Positive & $48.2 \%$ & $48.2 \%$ & $48.2 \%$ & $53.9 \%$ & $53.9 \%$ & $53.9 \%$ & $32.5 \%$ & $32.5 \%$ & $32.5 \%$ \\
\hline$\%$ Correctly Predicted & $75.7 \%$ & $73.2 \%$ & $69.9 \%$ & $76.1 \%$ & $70.9 \%$ & $67.8 \%$ & $80.7 \%$ & $78.3 \%$ & $77.1 \%$ \\
\hline
\end{tabular}

* t-statistics in parentheses

Table 2. Probit estimation of protection decision, excluding settled cases 
Title VII Cases

AD Cases

CVD Cases

\begin{tabular}{ccccccccc} 
A & B & C & A & B & C & A & B & C \\
\hline-0.1281 & -0.8949 & 0.1151 & -0.6207 & -1.2629 & -0.0625 & 0.2999 & -0.4740 & 0.1024
\end{tabular}

Constant

Size of Industry (+)

$(-0.22)$

0.1014

(0.10)

$-0.7552$

Concentration Ratio (+)

$(-1.12)$

0.2696

PAC Contributions (+)

(0.53)

\# of Representatives

0.1397

Ways \& Means Districts(+) (2.44)

\# of Representatives

Senate Finance States (+)

$\% \Delta$ Capacity Utilization (-)

$-0.0569$

$\% \Delta$ Shipments (-)

Named Country Import

Market Share (+)

Steel Industry Dummy (+)

LTFV Duty (+)

U.S. Trade Deficit (+/-)

Foreign Penetration (+)

U.S. Tariff Rate (-)

Non-market economy (+)

European country (-)

$$
\text { NIC (+) }
$$

$\operatorname{Japan}(+)$

Log Likelihood

Log Likelihood (constant only)

\# Observations

\# Obs. Positive

$\%$ Obs. Positive

$\%$ Correctly Predicted

* t-statistics in parentheses
$(-1.43)$

$-0.3865-0.6490$

$(-0.76) \quad(-1.31)$

$-0.2355-0.4096$

$(-0.33) \quad(-0.65)$

$1.4962 \quad 1.4505$

(3.37) (3.49)

$\begin{array}{ll}0.6607 & 0.8338\end{array}$

(2.96) (4.73)

$0.2060 \quad 0.2122$

(0.65) (0.68)

$-0.0030 \quad 0.0038$

$(-0.54) \quad(1.05)$

$0.5369 \quad 0.4144$

$(0.91) \quad(0.73)$
-1.4131

$-1.4131-0.5935$

$(-0.51) \quad(-0.25)$

$0.9015 \quad 0.8935$

(2.52)

(2.49)

$-0.2882$

$(-1.56) \quad(-1.86)$

$0.0635 \quad 0.1459$

(0.26) (0.62)

$\begin{array}{ll}-0.0012 \quad 0.0140 \\ (0.00) & (0.05)\end{array}$

(0.00)

(0.05)

$\begin{array}{lll}(0.21) & (-0.80) & (-2.46)\end{array}$

$-0.2362-0.2968$

$(-0.24) \quad(-0.25)$

$-0.7534-0.2950$

$(-1.16) \quad(-0.36)$

$0.7567 \quad 1.2823$

(1.56) (2.15)

$0.1390 \quad 0.1982$

(2.58) (3.11)

$-0.0388-0.0556$

$(-1.01) \quad(-1.18)$

$-1.1327$

$(-1.91)$

0.9490

(1.02)

0.9906

(1.91)

0.606

0.9524

(2.76) (3.70)

$0.0308 \quad 0.2925$

(0.10) (0.85)

$-0.0062$

$(-1.20)$

0.4785

(0.83)

$-0.4442$

$(-0.17)$

0.9149

(2.58)

$-0.3852$

$(-2.15)$

0.0083

(0.04)

0.2197

(0.84)

\begin{tabular}{ccccccccc}
-240.63 & -246.31 & -247.14 & -159.66 & -168.75 & -163.44 & -59.94 & -66.70 & -71.80 \\
-286.73 & -286.73 & -286.73 & -201.19 & -201.19 & -201.19 & -82.28 & -82.28 & -82.28 \\
434 & 434 & 434 & 315 & 315 & 315 & 119 & 119 & 119 \\
272 & 272 & 272 & 209 & 209 & 209 & 63 & 63 & 63 \\
$62.7 \%$ & $62.7 \%$ & $62.7 \%$ & $66.3 \%$ & $66.3 \%$ & $66.3 \%$ & $52.9 \%$ & $52.9 \%$ & $52.9 \%$ \\
$71.4 \%$ & $70.0 \%$ & $70.5 \%$ & $77.1 \%$ & $74.6 \%$ & $75.9 \%$ & $74.8 \%$ & $70.6 \%$ & $61.3 \%$ \\
\hline
\end{tabular}

Table 3. Probit estimation of protection decision, including settled cases

\begin{tabular}{|c|c|c|c|}
\hline$(-0.09)$ & $(0.19)$ & $(-0.59)$ & (0.08) \\
\hline-0.5790 & 1.1968 & & 2.7184 \\
\hline$(-0.49)$ & $(0.28)$ & & (1.03) \\
\hline-0.5691 & -0.2852 & & -0.8403 \\
\hline$(-0.72)$ & $(-0.13)$ & & $(-0.49)$ \\
\hline 1.4948 & -4.8079 & & -1.6579 \\
\hline$(2.61)$ & $(-2.12)$ & & $(-1.41)$ \\
\hline 0.1980 & -0.2460 & & -0.3042 \\
\hline (3.28) & $(-0.75)$ & & $(-1.68)$ \\
\hline-0.0557 & -0.0369 & & 0.1438 \\
\hline \multirow[t]{7}{*}{$(-1.23)$} & $(-0.20)$ & & (1.27) \\
\hline & 1.2283 & 1.3115 & \\
\hline & $(0.62)$ & (1.03) & \\
\hline & -3.4703 & -2.0548 & \\
\hline & $(-1.33)$ & $(-1.61)$ & \\
\hline & 5.9721 & 3.8917 & \\
\hline & $(3.60)$ & (3.10) & \\
\hline 0.8412 & -0.0522 & 0.4240 & 0.2286 \\
\hline (3.39) & $(-0.06)$ & $(0.87)$ & $(0.38)$ \\
\hline 0.2078 & -0.3770 & -0.9469 & -1.4074 \\
\hline$(0.61)$ & $(-0.26)$ & $(-0.77)$ & $(-1.12)$ \\
\hline-0.0076 & 0.0173 & 0.0016 & 0.0067 \\
\hline$(-1.69)$ & $(1.29)$ & $(0.26)$ & $(0.75)$ \\
\hline 0.2022 & 1.5408 & 2.1903 & 1.0472 \\
\hline$(0.30)$ & $(0.75)$ & (1.34) & $(0.64)$ \\
\hline-0.1188 & -13.4015 & -6.1391 & -2.8778 \\
\hline$(-0.04)$ & $(-1.31)$ & $(-0.96)$ & $(-0.43)$ \\
\hline \multirow{2}{*}{\multicolumn{4}{|c|}{$\begin{array}{c}0.9247 \\
(2.47)\end{array}$}} \\
\hline & & & \\
\hline-0.2790 & -0.3205 & -0.6167 & -0.4626 \\
\hline$(-1.24)$ & $(-0.73)$ & $(-1.73)$ & $(-1.21)$ \\
\hline \multicolumn{4}{|l|}{-0.0646} \\
\hline \multicolumn{4}{|l|}{$(-0.23)$} \\
\hline \multirow{2}{*}{\multicolumn{4}{|c|}{$\begin{array}{c}0.2252 \\
(0.77)\end{array}$}} \\
\hline & & & \\
\hline-163.44 & -59.94 & -66.70 & -71.80 \\
\hline-201.19 & -82.28 & -82.28 & -82.28 \\
\hline 315 & 119 & 119 & 119 \\
\hline 209 & 63 & 63 & 63 \\
\hline $66.3 \%$ & $52.9 \%$ & $52.9 \%$ & $52.9 \%$ \\
\hline $75.9 \%$ & $74.8 \%$ & $70.6 \%$ & $61.3 \%$ \\
\hline
\end{tabular}

$(-0.09)$
-0.5790

(0.19)

2.7184

0.8403

1.6579

$(-1.41)$

$(-1.68)$

0.1438

$-1.4026$

$(-2.44)$

0.0071

$0.01)$

(2.40)

0.2915

(0.87)

0.0056

(1.59)

$\begin{array}{ll}(-1.23) & (1.59) \\ 0.0845 & -0.0462\end{array}$

$(0.12) \quad(-0.07)$

$-0.2246-0.4330$

$(-0.07)$

$(-0.15)$

0.9312

(2.42)

$-0.1916$

$(-0.83) \quad(-0.86)$

$0.0034 \quad 0.0889$

(0.33)

0.1183

0.1224

(0.41)

\begin{tabular}{ccccccccc}
-240.63 & -246.31 & -247.14 & -159.66 & -168.75 & -163.44 & -59.94 & -66.70 & -71.80 \\
-286.73 & -286.73 & -286.73 & -201.19 & -201.19 & -201.19 & -82.28 & -82.28 & -82.28 \\
434 & 434 & 434 & 315 & 315 & 315 & 119 & 119 & 119 \\
272 & 272 & 272 & 209 & 209 & 209 & 63 & 63 & 63 \\
$62.7 \%$ & $62.7 \%$ & $62.7 \%$ & $66.3 \%$ & $66.3 \%$ & $66.3 \%$ & $52.9 \%$ & $52.9 \%$ & $52.9 \%$ \\
$71.4 \%$ & $70.0 \%$ & $70.5 \%$ & $77.1 \%$ & $74.6 \%$ & $75.9 \%$ & $74.8 \%$ & $70.6 \%$ & $61.3 \%$ \\
\hline
\end{tabular}


Drop Political Variables (A vs. B)

Drop Economic Injury Variables (A vs. C)

Drop Political Variables (A vs. B)

Drop Economic Injury Variables (A vs. C)

\section{Excluding Settled Cases}

\begin{tabular}{ccc} 
Title VII Cases & AD Cases & CVD Cases \\
\hline 0.02115 & 0.00448 & 0.21415 \\
0.00182 & 0.04347 & 0.00496
\end{tabular}

Including Settled Cases

\begin{tabular}{ccc} 
Title VII Cases & AD Cases & CVD Cases \\
\hline 0.04459 & 0.00273 & 0.01902 \\
0.00459 & 0.05631 & 0.00003
\end{tabular}

* Numbers in table indicate marginal significance of dropping variables

Table 4. Likelihood ratio test of significance 
Petitioning Industry with 3 additional Ways \& Means Oversight Member (4)

$18.71 \% \quad 24.14 \%$

Fall in Capacity Utilization of $20 \%(-5 \%)$

$4.33 \% \quad 5.16 \%$

Increase Import Market Share of Named Country by $0.20(0.15)$

$14.51 \% \quad 11.06 \%$

Steel Industry (dummy)

$36.59 \% \quad 36.59 \%$

Increase LTFV Duty by $0.27(0.23)$

$6.53 \% \quad 6.49 \%$

Non-market Economy (dummy)

$39.00 \%$

$37.65 \%$

Western European Economy (dummy)

$-17.34 \% \quad-15.58 \%$

* Based on specification A, "Excluding settled cases" dataset; sample means in parentheses

Table 5. Estimated change in probability of affirmative decision 
Summary Statistics - Independent Variables

(excluding settled cases)

Domestic Politics Variables

Industry Power:

Size of Industry (million employees)

Concentration Ratio

Political Activity:

PAC Contributions (million 1982\$)

Political Representation:

\# of Representatives Ways \& Means Districts

\# of Representatives Senate Finance States

Economic Injury:

$\% \Delta$ Capacity Utilization

$\% \Delta$ Shipments

Named Country Import Market Share

\section{Control Variables}

Case Specific Factors:

Steel Industry Dummy

LTFV Duty

Macro-economic Control Factors:

U.S. Trade Deficit (billion 1982\$)

Micro-economic Control Factors:

Foreign Penetration

U.S. Tariff Rate

Named Country Control:

Non-market economy

European country

NIC

Japan

$\begin{array}{cccccc}\text { Mean } & \text { Sum } & \text { Std. Dev. } & \text { Median } & \text { Max } & \text { Min } \\ & & & & & \\ 0.13 & 40.86 & 0.12 & 0.08 & 0.49 & 0.0013 \\ 0.39 & 120.65 & 0.16 & 0.42 & 0.93 & 0.07 \\ & & & & & \\ 0.19 & 60.58 & 0.20 & 0.14 & 0.83 & 0.0009 \\ & & & & & \\ 3.92 & 1227.00 & 2.84 & 5.00 & 12.00 & 0.00 \\ 8.47 & 2651.00 & 3.12 & 9.00 & 19.00 & 0.00 \\ & & & & & \\ -0.03 & -8.98 & 0.22 & -0.04 & 0.60 & -0.36 \\ -0.04 & -11.16 & 0.18 & -0.01 & 0.44 & -0.35 \\ 0.15 & 47.84 & 0.20 & 0.06 & 1.00 & 0.000034 \\ & & & & & \\ & & & & & \\ 0.55 & 172.00 & 0.50 & 1.00 & 1.00 & 0.00 \\ 0.24 & 75.72 & 0.27 & 0.17 & 1.94 & 0.01 \\ & & & & & \\ 90.55 & 28343.18 & 47.19 & 112.49 & 159.56 & 25.50 \\ & & & & & \\ 0.18 & 54.94 & 0.13 & 0.17 & 0.78 & 0.00 \\ 0.06 & 19.74 & 0.03 & 0.06 & 0.19 & 0.00 \\ & & & & & \\ 0.07 & 21.00 & 0.25 & 0.00 & 1.00 & 0.00 \\ 0.40 & 125.00 & 0.49 & 0.00 & 1.00 & 0.00 \\ 0.13 & 41.00 & 0.34 & 0.00 & 1.00 & 0.00 \\ 0.12 & 38.00 & 0.33 & 0.00 & 1.00 & 0.00\end{array}$

